\title{
Meillassoux, Correlationism, and the Ontological Difference
}

\author{
G. Anthony BRuno
}

The realist credentials of post-Kantian philosophy are often disputed by those who worry that grounding ontology on the human standpointvariously construed by Kant, German idealism, phenomenology, and existentialism - bars us from an otherwise accessible reality, impoverishing our cognitive grasp, and betraying the promise of natural science. While many such critics ally with the so-called analytic tradition, the past decade has seen the rise of thinkers versed in the so-called continental tradition who, under the loose and controversial banner of "speculative realism," seek to overcome the alleged anthropocentrism of Kantian and post-Kantian thought by developing theories of cognitive access to human-transcendent being.

Although proponents of speculative realism include Ray Brassier, Levi Bryant, Iain Hamilton Grant, and Graham Harman, my focus will be on Quentin Meillassoux, whose work has been influential both within this movement and for its sympathizers. It is Meillassoux who coins "correlationism" to name the view that we can only access the mutual dependence of thought and being and that, consequently, neither is explicable in isolation, even by the natural sciences (Meillassoux 5). And it is Meillassoux who, in his monograph After Finitude, traces correlationism to Kant's Copernican revolution and claims its apotheosis to include Heidegger's phenomenological claim that an understanding of being cannot dispense with an existential analysis of subjectivity. On this view, the question of being is inextricably bound to the question of the meaning of being for such beings as ourselves.

Attributing correlationism to Heideggerian phenomenology, as Meillassoux does, implies that it places a rational distinction between thought and being according to which neither is intelligible independently of the other. To borrow a McDowellian phrase, this is the idea that neither thought nor being makes a notionally separable contribution to ontological understanding. But is this a felicitous portrayal? Does Meillassoux's notion of correlationism address the ontological difference between being and beings that lies at the heart of Heidegger's phenomenology? If not, does he talk past Heidegger when criticizing his brand of realism? 
Meillassoux specifies his general conception of correlationism as the denial that we have independent access to the realms of either "subjectivity" or "objectivity" (5). He also specifies the general thoughtbeing correlation as a correlation between thinker and thing, language and referent, noesis and noema, intending these variations to cover all postKantian versions of correlationism (4-6). Meillassoux's specification implies that Heidegger rejects any direct contact with the ontic domains of either subjects or objects. ${ }^{1}$ This is accurate insofar as, for Heidegger, I cannot access the domain of subjects in isolation from their relations of significance to the domain of useful objects, just as I cannot access the domain of objects without reference to the contexts of significance in which the cognitive and coping activity of subjects occurs. I initially find myself bound to the things at hand, just as surely as a boat unknown to me implicitly refers to another who did, does, or may voyage with it (see Heidegger, Being and Time 57, 111).

However, these specifications of correlationism do not exhaust the relevant meaning of being for Heideggerian phenomenology, or so I will argue. It is only because we have access to being - through an existential analysis of the structures in virtue of which anything is manifest to us - that we can distinguish different classes of beings. In other words, the very idea of an ontic domain of beings - a fortiori the very idea of that domain's notional inseparability from another such domain-presupposes an ontological understanding of being. But this is just to say that comprehending ontic domains presupposes our access to being as such, which complicates Meillassoux's attribution of correlationism. This is further complicated by Meillassoux's common description of correlation in the ontic terms of an entity, such as a thing, given to another entity, such as a thinker (see Meillassoux 37). His criticism of Heidegger can accordingly be shown to rest on an inapt portrayal, one that ignores the ontological difference that drives Heidegger's phenomenological project.

This paper is structured as follows. In the first section, I will reconstruct Meillassoux's account of correlationism and demonstrate its inadequacy as a criticism of Heideggerian phenomenology. In the second section, I will offer a diagnosis of Meillassoux's misreading of Heidegger, arguing that his failure to fully register the ontological difference stems from a question-begging appeal to transcendental realism. Meillassoux's commitment to transcendental realism is deeply at odds with Heidegger's twin claims in Being and Time that (1) philosophy's possibility lies in the "idealist insight" that being is not explicable in terms of beings and that (2) phenomenological truth is just transcendental truth. I will suggest that reading these claims together can clarify Heidegger's brand of realism and

\footnotetext{
${ }^{1}$ Meillassoux attributes to Heidegger, and to all post-Kantians, "the replacement of adequation by intersubjectivity in the redefinition of scientific objectivity" (8).
} 
his account of the presuppositions of experience and natural science. I will conclude in the third section with a brief reflection on how to view Heidegger's realism in relation to transcendental idealism.

\section{I.}

Before assessing Meillassoux's account of correlationism, it is useful first to consider the perceived need for the kind of philosophical project that he aims to develop. The need arises in response to the post-Kantian weakening of necessity, which results in the inability to grasp "the absolute," that is, the world as independent of its givenness in human experience. In particular, the pre-Kantian commitment to what Meillassoux calls "real necessity" (32) — a commitment that consists in affirming the existence of a necessary entity - is rejected by Kant as dogmatic insofar as this sort of necessity is foreign to the conditions that are constitutive of the human standpoint. In its place, Kant provides a critical account of what I will call the "anthropic necessity" that characterizes the conditions of the possibility of our experience. For Meillassoux, however, the deduction of this kind of necessity secures no more than, to borrow his phrase, "necessity for us" (3032).

In the A Preface to the Critique of Pure Reason, Kant identifies the advantage of abandoning real necessity as the institution of a "court of justice, by which reason may secure its rightful claims while dismissing all its groundless pretensions," in particular, the various and incompatible claims to knowledge of a necessary entity that render metaphysics an anarchy of assertion (Aviii-Axi). This court of justice, which is "none other than the critique of pure reason itself," serves the "most difficult" task of "self-knowledge" (Axi-Axii ), that is, knowledge of the nature and bounds of our understanding. According to Meillassoux, by replacing real necessity with anthropic necessity, we overcome metaphysical anarchy, but at the cost of subjectivizing ontology: our search for self-knowledge blinds us to the great outdoors, that is, to "that outside which was not relative to us" (7). In particular, we unduly exclude the absolute outside if we restrict necessity to the conditions of our experience because this neglects the alternative, which Meillassoux defends, that contingency itself is necessary, that is, that everything "is without reason, and is thereby capable of actually becoming otherwise without reason" (53). If contingency is "an absolute ontological property, and not the mark of the finitude of our knowledge" (53), then we can speak of necessity while avoiding both metaphysical anarchy and subjective ontology. Only then can we pursue "intellectual intuition of the absolute" (82).

For Meillassoux, then, we neglect the necessity of contingency if we confine understanding to the correlation between thought and being. 
Specifying his general definition of correlationism in ontic terms, he says that it

disqualif[ies] the claim that it is possible to consider the realms of subjectivity and objectivity independently of one another. Not only does it become necessary to insist that we never grasp an object in itself, in isolation from its relation to the subject, but it also becomes necessary to maintain that we can never grasp a subject that would not always already be related to an object (5).

For both Kant and Heidegger, the subject-object correlation appears to be unsurpassable. In a Kantian fashion, the subject is theoretically no more than a function that unifies representations of objects, the possible experience of which is in turn conditioned by the subject's cognitive activity. In a Heideggerian fashion, the subject is always already situated in a totality of significance populated by useful objects whose existence inescapably implies their handiness for subjects.

Crucially, both the Kantian and the Heideggerian descriptions of the subject-object correlation are articulated in terms of anthropic necessity. As Kant says, the apperceptive unity of my representations "declares as necessary a synthesis of the manifold given in an intuition, without which that thoroughgoing identity of self-consciousness could not be thought," while the combination of the intuitive manifold is "only an operation of the understanding, which is itself nothing further than the faculty of combining a priori and bringing the manifold of given representations under unity of apperception" (B135). ${ }^{2}$ Beyond this apperceptive correlation, representations of nature "would either be impossible or else at least would be nothing for me" (B132). Likewise, for Heidegger, Dasein's a priori absorption in contexts of significance entails that it "has always already referred itself to an encounter with a "world"' of useful objects (Being and Time 87). At the same time, objects' handiness for us is their "ontological categorial definition," insofar as Dasein is the "condition of the possibility of the disclosure of beings encountered in the mode of being of relevance (handiness)" (71,87). Nature is only comprehensible within this correlation of handiness and otherwise "remains hidden" from us (66).

Meillassoux asserts that we are "truly imprisoned" (7) by Kantian and Heideggerian accounts of anthropic necessity, distinguishing these accounts as, respectively, "weak" and "strong" varieties of correlationism. Kant's is a minimum-security prison because it "does not prohibit all

\footnotetext{
${ }^{2}$ See Goldman (112-113): "in order to say something about this subject, this transcendental unity of apperception, we must conceive of its predicates, the objects of thought, and yet, these objects always already make use of that which they would purport to explain, as for Kant an object cannot be thought without presupposing such an underlying unity."
} 
relation between thought and the absolute. It proscribes any knowledge of the thing-in-itself [...] but maintains the thinkability of the in-itself" (35). By contrast, Heidegger's maximum-security prison "maintains not only that it is illegitimate to claim that we can know the in-itself, but also that it is illegitimate to claim that we can at least think it" (35). Kant defends the idea of the absolute, although his cognitive restriction on it prevents him from grasping it otherwise than as a regulative task of reason. The "exacerbated consequence" of this "Kantian catastrophe" (124) is Heidegger's apparent repudiation of even the regulative idea of the great outdoors beyond correlation. $^{3}$

Meillassoux's main textual evidence for characterizing Heidegger as a strong correlationist is the following passage from "On the Question of Being":

We always say too little of "being itself" when, in saying "being," we omit its essential presencing in the direction of the human essence and thereby fail to see that this essence itself is part of "being." We also say too little of the human being when, in saying "being" (not being human), we posit the human being as independent and then first bring what we have thus posited into a relation to "being" (Pathmarks 308).

This passage appears to support a strong correlationist interpretation of Heideggerian phenomenology, for it denies independent intelligibility to both being and human beings. If neither term is notionally distinct for ontological understanding, and if transcending them is not even thinkable, then we seem to be trapped in the maximum-security prison described above.

Three sentences later, however, Heidegger continues:

the subject-object relation [...] says that to every subject (human being) there belongs an object (being), and vice versa. Certainly; were it not for the fact that all of this - the relation, the subject, and the object-already resides within the essence of what we are representing [...] Subjectivity and objectivity are for their part already grounded in a peculiar manifestness of "being" and of the "human essence." Such manifestness establishes representation in terms of the distinction between the two as subject and object. This distinction henceforth becomes absolute and banishes thinking into a dead end. Any positing of "being" that would seek to name "being" from the perspective of the subject-object relation fails to ponder something worthy of question that it has left unthought (308).

\footnotetext{
${ }^{3}$ For an account of the structural analogy between Kant's regulative idea of the thing in itself and Heidegger's idea of death, see Bruno (“A Peculiar Fate").
} 
Heidegger's claim in this passage is that any representation of the subjectobject (or thinker-thing) relation is already "establish[ed]" or "grounded" in the "essence" that phenomenology interrogates, namely, the comanifestation of being and human Dasein. The essence of this comanifestation is unlike the essences of subjects and objects, which are ontically distinguished into classes of beings. Rather, this essence is ontological. We can see why this is so by considering two points. First, being does not fall into a class of beings, for it is that in virtue of which beings have their being. Second, as Heidegger argues in Being and Time, because any understanding of being necessarily implicates the "constitutive attitudes of inquiry" of "the being we inquirers ourselves in each case are," fundamental ontology "must be sought in the existential analysis of Dasein" $(5,11)$. And we inquirers are not merely ontic: Dasein "is ontically distinguished by the fact that in its being this being is concerned about its very being." This means that "Understanding of being is itself a determination of being of Dasein. The ontic distinction of Dasein lies in the fact that it is ontological" (10). The essence that "establishes" the subjectobject (or thinker-thing) relation is accordingly the ontological comanifestation of being and Dasein.

Conceiving this essence presupposes the ontological difference between being as such and such beings as subjects and objects (or thinkers and things), a difference that enables the phenomenologist to formulate the question of the meaning of being in the first place. We stifle this philosophical questioning - "banish[ing] thinking into a dead end"-if we view the subject-object relation as "absolute," for we thereby lapse into prejudicial neglect of this "worthy" question. Heidegger accordingly rejects Meillassoux's ontic gloss of the strong correlationist thesis, according to which the subject-object (or thinker-thing) relation is absolute. ${ }^{4}$ Meillassoux attributes this thesis to Heidegger in spite of the latter's commitment to the ontological difference that, as the above passage shows, undermines it. What can account for Meillassoux's misreading?

II.

Before answering this question, let us consider an objection to the interpretation of the second passage from "On the Question of Being" offered above. To the claim that the ontic relation between subjects and objects rests on an existentially oriented ontology, Meillassoux may object that this only shifts the correlation from the subject-object relation to the being-Dasein relation, in which case Heidegger is simply a correlationist at a deeper level. Indeed, just prior to the second passage, Heidegger states

${ }^{4}$ See, for example, Heidegger (Being and Time 56): "subject and object are not the same as Dasein and world." 
that "there already lies within the human essence the relation to that which - through a relation, a relating in the sense of needful usage - is determined as 'being' and so through this relation is removed from its supposed "self-independence"" (308). It may be that Heidegger is a correlationist at the level of the "relation" between human Dasein and being. However, to what would such an objection amount?

Just after the second passage quoted above, Heidegger explains that any question of the "relation" between human Dasein and being is "inadequate because it never attains to the realm of what it seeks to ask after. In truth we cannot then even continue to say that 'being' and 'the human being' 'are' the Same in the sense that they belong together; for when we say it in this way, we continue to let both subsist independently" (309). If fundamental ontology is properly pursued through an existential analysis of Dasein, and if Dasein's being is distinctly ontological, then phenomenology is not oriented by a relation between independently existent relata, but rather by a single essence that is doubly meaningful. Neither being nor Dasein provide a notionally separable contribution to ontological understanding. Their co-manifestation provides the grounding essence that makes possible the relation between subjects and objects (or thinkers and things). If positing this essence amounts to correlationism at a deeper level, what is thereby excluded? Perhaps, as Meillassoux claims, it is the great outdoors, that is, the "absolute outside" that was never relative to us. However, we cannot simply appeal to the latter by assuming it as the standard for realism. As I will now show, Meillassoux assumes precisely this.

In After Finitude, Meillassoux asserts that "every variety of correlationism is exposed as an extreme idealism, one that is incapable of admitting that what science tells us about [...] occurrences of matter independent of humanity effectively occurred as described by science" (18). Statements referring to events "anterior to terrestrial life and hence anterior to givenness itself" are "ancestral" (20), according to Meillassoux, insofar as they refer to reality independent of human experience. In other words, the ancestral statements of science purport to refer to transcendental reality. Weak and strong correlationists, who permit themselves only to speak of objects' givenness in experience, must reject ancestral statements so construed. Against this apparently unscientific view, Meillassoux mounts his "argument from the arche-fossil" (18-20):

(A1) realism affirms the ancestral statements of science;

(A2) since these statements refer to transcendental reality, a correlationist must deny them; thus,

(A3) a correlationist has no legitimate claim to realism.

This argument entails that neither Kant nor Heidegger is in any sense a realist. However, we can see that it begs the question, since one of its 
premises and its conclusion both imply that transcendental realism is true. According to (A2), ancestral statements successfully refer only because they refer to transcendental reality, and transcendental realism is true. According to (A3), a correlationist has no claim to realism because she is an idealist, idealism is "incapable of referring to transcendental reality," and transcendental realism is true. Meillassoux's argument from the arche-fossil simply assumes that transcendental reality is the only standard for realism. This is particularly problematic because he presents his speculative realist position as a solution to the apparent problem of Kantian and post-Kantian idealism (see Meillassoux 121).

Kant, of course, is committed to empirical realism, which he identifies with transcendental idealism. He asserts "at the same time" the empirical reality and transcendental ideality of space and time, such that they have "objective validity," and thus are empirically real, even as they form "the constitution of our sensibility," and thus are transcendentally ideal (A28/B44). As Kant says in the Paralogisms, "the transcendental idealist is an empirical realist": only the empirical realist can assert with justification that "outer perception proves something real in space [and time]," since only she comprehends space and time as "sensible forms of our intuition" (A369, 371, 375). Given the identity of empirical realism and transcendental idealism, statements about reality as it now appears to us and statements about reality prior to human life cannot differ in kind, as if the former refer to empirical reality while the latter refer-per impossibile- to transcendental reality. Rather, they differ in degree, for statements about the ancestral past are no less empirically bound than statements about the present.

Of course, empirical realism may be false. However, we cannot prove this by adducing its contradiction - transcendental realism - as a reason against it. That is to argue in a circle. Meillassoux requires an independent argument in favour of transcendental realism, one that does not simply gainsay empirical realism. ${ }^{5}$ Again, the onus is on him precisely because he has set himself the task of overcoming the alleged "Kantian catastrophe" and its "exacerbated consequence" in Heideggerian phenomenology.

Meillassoux's question-begging appeal to transcendental realism subverts his critique of post-Kantian idealism and empirical realism, the

\footnotetext{
${ }^{5}$ It will not be sufficient to object, as Meillassoux does, that empirical realism relies on a "more originary correlationist meaning" set by the anthropic conditions of experience (14). Even granting that empirical realism ultimately rests on, say, a being-Dasein correlation (which, as we saw, Heidegger is reluctant to construe as a relation), this is only objectionable on the basis of a non-question-begging argument in favour of transcendental realism, which Meillassoux does not provide.
} 
other side of its coin. The circularity of his appeal is, I suggest, what accounts for his neglect of the ontological difference. I will now turn to Heidegger's espousal of the ontological difference, which relies on twin claims in favour of a variety of transcendental idealism.

The first claim footnotes the first of three mentions of the ontological difference in Being and Time: "If the term idealism amounts to an understanding of the fact that being is never explicable by beings, but is always already the 'transcendental' for every being, then the sole correct possibility of a philosophical problematic lies in idealism" (193). Where idealism explains being in terms of such beings as minds, it is, Heidegger says, "psychological" (192). But where idealism gives philosophy its proper orientation, it explains beings in terms of being as such, that is, in terms of the conditions through which being as such is manifest to us and thus has any meaning. This sort of idealism is transcendental insofar as it properly conceives of the ontological difference. Heidegger's claim reflects Kant's assertion in the Doctrine of Method that transcendental philosophy "considers only the understanding and reason itself in a system of all concepts and principles that are related to objects in general, without assuming objects that would be given" (A845/B873, emphasis added). Heidegger himself discerns the ontological difference in Kant's philosophy in his Phenomenological Interpretation of Kant's Critique of Pure Reason:

Beings are in no way accessible without an antecedent understanding of being. This is to say that beings, which encounter us, must already be understood in advance in their ontological constitution. This understanding of the being of beings, this synthetic knowledge a priori, is crucial for every experience of beings. This is the only possible meaning of Kant's thesis, which is frequently misunderstood and which is called his Copernican revolution (38).

Heidegger's second claim occurs during his description of phenomenology as the "science of the being of beings": "Phenomenological truth (disclosedness of being) is veritas transcendentalis" (Being and Time 3334). This claim is the twin of the first. This is because the truth that phenomenology discloses about being is transcendental truth if and only if, as the first claim states, transcendental philosophy orients us toward being as the explanatory ground of beings.

Together, these twin claims throw light on William Blattner's observation that Heidegger holds the empirical realist view that "there are no general reasons to doubt the truth of scientific claims, and no need to distinguish scientific claims from ordinary ones" (186). If empirical realism is identical to transcendental idealism, as Kant argues, and if Heidegger identifies phenomenology with a variety of transcendental idealism, then it should come as no surprise that Heidegger espouses empirical realism. 
Indeed, Heidegger implies his awareness of the identity of empirical realism and transcendental idealism when he describes the resolution of the traditional debate between realism and idealism in History of the Concept of Time:

In elucidating these positions it is not so much a matter of clearing them up or of finding one or the other to be the solution, but of seeing that both can exist only on the basis of a neglect: they presuppose a concept of 'subject' and 'object' without clarifying these basic concepts with respect to the basic composition of Dasein itself (222223).

Heidegger views the traditional realism-idealism debate as an antinomy whose parties jointly fail to grasp subjectivity and objectivity on the basis of a more fundamental essence, namely, an analysis of Dasein, which is the starting point of fundamental ontology. This failure is the spoiling ingredient that Heidegger attributes in "On the Question of Being" to those who ponder the subject-object relation in abstraction from the question of the meaning of being. Those who do so neglect the fact that the subjectobject (or thinker-thing) relation - and therefore any position we might take on the realism-idealism debate-is grounded in the peculiar comanifestation of being and Dasein, a co-manifestation that is a uniquely phenomenological, or transcendental, truth.

It is no wonder, then, that Meillassoux neglects the ontological difference when deferring to natural science in an attempt to refute Heidegger. By begging the question in favour of transcendental realism, he prevents himself from critiquing Heidegger's variety of transcendental idealism on its own terms.

\section{III.}

Given Heidegger's various criticisms of Kant, we might be struck by the thought that he espouses a variety of transcendental idealism. We may therefore wish to identify the essential marks of this philosophical position, beyond its identity with empirical realism. I will conclude by offering three such marks.

The first is the apriority of space and time, on which rests the transcendental idealist distinction between appearances and the thing in itself. Although Kant and Heidegger have quite different conceptions of space and time, they share a commitment to their apriority. Kant develops the idea of an appearance from an analysis of the form of human sensibility. He argues that since we can imagine the absence of extended or enduring objects, but not the absence of space or time, space and time must be a priori "condition[s] of the possibility of appearances" (A24/B38-39). I have argued elsewhere that Heidegger likewise affirms the apriority of space and 
time for Dasein (Bruno, "Varieties"). He claims, for example, that space is the "basic constitution of the world" in which we always already find ourselves and pursue our ends, and that time "makes possible the being of care," or the concernfulness for things, that defines Dasein's existence. (History 224, 320). Given Heidegger's commitment to the apriority of space and time, he unsurprisingly respects the transcendental idealist distinction that rests on it, defending Kant's account of appearances as well as his proscription of knowledge of the thing in itself in his Phenomenological Interpretation of the first Critique (67-69).

This points to a second mark: only a boundary concept can represent the unity of human experience. For transcendental idealism, experience is defined in part by its pursuit of a unity that it can conceive but can never actualize. This unity is accordingly a regulative ideal. Such an ideal can be construed in terms of systematic knowledge, following Kant, or in terms of fully owned existence, following Heidegger. For both philosophers, experience is a purposive activity whose telos individuates it by always remaining outstanding for it, that is, by being a task of constant striving rather than a given. In a slogan: no striving, no experience. Whereas Kant relies on a boundary concept in order to demarcate the bounds of sense, Heidegger does so in order to demarcate the bounds of life.

A third mark of transcendental idealism is its status as a thesis, not about consciousness or the mind, but rather about the radical contingency of the conditions of human experience. Neither the conditions that Kant secures through transcendental reflection nor the conditions that Heidegger discovers through existential analysis are logically necessary. Their absence would pose no contradiction as far as general logic is concerned, that is, it would not violate the principle of non-contradiction. However, for transcendental logic, the conditions of experience are anthropically necessary or, as Heidegger will say, factical. Transcendental logic sets a higher standard for what can count as necessary: claims to know real necessity devolve into metaphysical anarchy precisely because they fail to consider the specific conditions that our perspective places on what we can know, scientifically and in ordinary experience. Such conditions are necessary only given the brute fact of the purposive activity into which, as finite subjects, we are thrown.

\section{Conclusion}

Whether or not what Heidegger regards as the fundamental relation between being and Dasein is a (cor)relation, it is meant to ground the natural scientific explanations on whose behalf Meillassoux mounts his critique of phenomenology. Heidegger's insight is to subordinate the common and tempting question of our place within nature to the more difficult and authentic question of nature's place with respect to our distinctly 
ontological activity. Phenomenology thereby interrogates being in terms of the anthropic conditions of its disclosure, extending Kant's Copernican turn.

On a broadly transcendental idealist picture, such conditions do not warrant knowledge of an alleged absolute outside, whether construed in the pre-Kantian terms of real necessity or in Meillassoux's terms as the necessity of contingency. As I have argued, Meillassoux's critique of this restriction in Heidegger, particularly given its neglect for the ontological difference, begs the question against Heidegger's post-Kantian account of anthropic necessity. Heideggerian phenomenology cannot thereby be deemed an "exacerbated consequence" of a "Kantian catastrophe," for this would depend on a still lacking argument for why transcendental idealism is catastrophic. Given the dogmatic and skeptical pitfalls of its alternative, transcendental idealism is as well grounded as any realism with a human face.

\section{Works Cited}

BLATTNER, William. "Is Heidegger a Kantian Idealist?” Inquiry 37, no. 2 (1994): 185-201.

BRUNO, G. Anthony. "A Peculiar Fate: Kant and Heidegger on the Unity of Human Life." Dialogue: Canadian Philosophical Review 53, no. 4 (2014): 715-735.

- " "Varieties of Transcendental Idealism: Kant and Heidegger Thinking Beyond Life." Idealistic Studies 45, no. 1 (2015): 81-102.

GOLDMAN, Avery. "Kant, Heidegger and the Circularity of Transcendental Inquiry." Epoché 15, no. 1 (2010): 107-120.

HEIDEGGER, Martin. History of the Concept of Time. Trans. Theodore Kisiel. Bloomington: Indiana University Press, 1985.

—. Being and Time. Trans. Joan Stambaugh. Albany: SUNY Press, 1996.

-. Phenomenological Interpretation of Kant's Critique of Pure Reason. Trans. Parvis Emad and Kenneth Maly. Bloomington: Indiana University Press, 1997.

-. "On the Question of Being." Pathmarks. Ed. William McNeill.

Cambridge: Cambridge University Press, 1998. 291-322.

KANT , Immanuel. Critique of Pure Reason. Trans. Paul Guyer and Allen Wood. Cambridge: Cambridge University Press, 1998.

MEILLASSOUX, Quentin. After Finitude: An Essay on the Necessity of Contingency. Trans. Ray Brassier. London: Continuum, 2009. 